Article

\title{
Study on Decomposition of Indoor Air Contaminants by Pulsed Atmospheric Microplasma
}

\author{
Kazuo Shimizu *, Tomoya Kuwabara and Marius Blajan \\ Organization for Innovation and Social Collaboration, Shizuoka University, 3-5-1 Johoku, Nakaku, \\ Hamamatsu 432-8561, Japan; E-Mails: wave_the_jolly_roger@yahoo.co.jp (T.K.); \\ blajanmarius@yahoo.com (M.B.)
}

* Author to whom correspondence should be addressed; E-Mail: shimizu@ @jr.shizuoka.ac.jp; Tel./Fax: +81-053-478-1443.

Received: 7 September 2012; in revised form: 19 October 2012 / Accepted: 22 October 2012 / Published: 29 October 2012

\begin{abstract}
Decomposition of formaldehyde (HCHO) by a microplasma reactor in order to improve Indoor Air Quality (IAQ) was achieved. HCHO was removed from air using one pass through reactor treatment $(5 \mathrm{~L} / \mathrm{min})$. From an initial concentration of $\mathrm{HCHO}$ of $0.7 \mathrm{ppm}$ about $96 \%$ was removed in one pass treatment using a discharge power of $0.3 \mathrm{~W}$ provided by a high voltage amplifier and a Marx Generator with MOSFET switches as pulsed power supplies. Moreover microplasma driven by the Marx Generator did not generate NOx as detected by a chemiluminescence NOx analyzer. In the case of large volume treatment the removal ratio of $\mathrm{HCHO}$ (initial concentration: $0.5 \mathrm{ppm}$ ) after 60 minutes was $51 \%$ at $1.2 \mathrm{kV}$ when using $\mathrm{HV}$ amplifier considering also a $41 \%$ natural decay ratio of $\mathrm{HCHO}$. The removal ratio was $54 \%$ at $1.2 \mathrm{kV}$ when a Marx Generator energized the electrodes with a $44 \%$ natural decay ratio after 60 minutes of treatment.
\end{abstract}

Keywords: microplasma; dielectric barrier discharge; pulsed power; air treatment

\section{Introduction}

Volatile Organic Compounds (VOCs) are a problem in indoor spaces as their presence worsens the indoor air quality (IAQ). Together with malodorous substances, fungus, bacteria and tobacco smoke they cause so called sick building syndrome $[1,2]$. Formaldehyde (HCHO) is one of these VOCs. Its 
concentration in indoor air is regulated at $0.08 \mathrm{ppm}$ by the Japanese Ministry of Health, Labor and Welfare (MHLW).

Active solutions can be applied for improving the indoor air quality. One of them could be an atmospheric pressure non-thermal plasma. Its generation starts from $8 \mathrm{kV}$, thus bulky power supplies and reactor are necessary [3-6]. Microplasmas, which are a dielectric barrier discharge non-thermal plasma, are generated at about $1 \mathrm{kV}$ between electrodes faced together with a discharge gap on the order of micrometers. Thus the size of the needed reactor and power supply are decreased considerably, making this technology suitable for integration in home appliances such as air conditioners $[7,8]$.

The decomposition of formaldehyde using dielectric barrier discharge was reported by Storch and Kushner [9]. A similar type of barrier discharge was used having a discharge gap of $2 \mathrm{~mm}$ and electrodes were energized with voltages up to $40 \mathrm{kV}$. The capability of a microplasma to remove low concentrations of $\mathrm{HCHO}$ in room air (below $1 \mathrm{ppm}$ ) for improving IAQ was investigated. The HCHO removal ratio was $97 \%$ at the discharge power of $0.3 \mathrm{~W}$ and $5 \mathrm{~L} / \mathrm{min}$ gas flow rate. Various radicals $\left(\mathrm{N}^{*}, \mathrm{O}^{*}, \mathrm{OH}^{*}\right.$, etc. $)$ generated by the microplasma reacted with the VOC and decomposed it. Aroma sensory assessment was carried out by a fragrance analyzer with 10 semiconductor sensors. The microplasma changed the gas smell tendency and the odor index was reduced.

This paper presents the results of $\mathrm{HCHO}$ treatment by a microplasma at gas flow rates of $5 \mathrm{~L} / \mathrm{min}$. Experiments were carried out with microplasma electrodes energized by an AC and a pulse power supply in order to determine the optimal power supply for microplasma HCHO treatment.

\section{Experimental Section}

Microplasma electrodes are perforated stainless steel plates covered with a dielectric layer of $200 \mu \mathrm{m}$ thickness. Electrodes used in this study were of circular shape $\varnothing 58 \mathrm{~mm}$, aperture ratio $36 \%$ and placed facing each other at $100 \mu \mathrm{m}$ distance using a spacer. Due to the small discharge gap and to the dielectric constant of the dielectric layer of about $\mathrm{gr}=10^{4}$, a high intensity electric field $\left(10^{7} \sim 10^{8} \mathrm{~V} / \mathrm{m}\right)$ could be obtained.

Figure 1. A microplasma reactor.

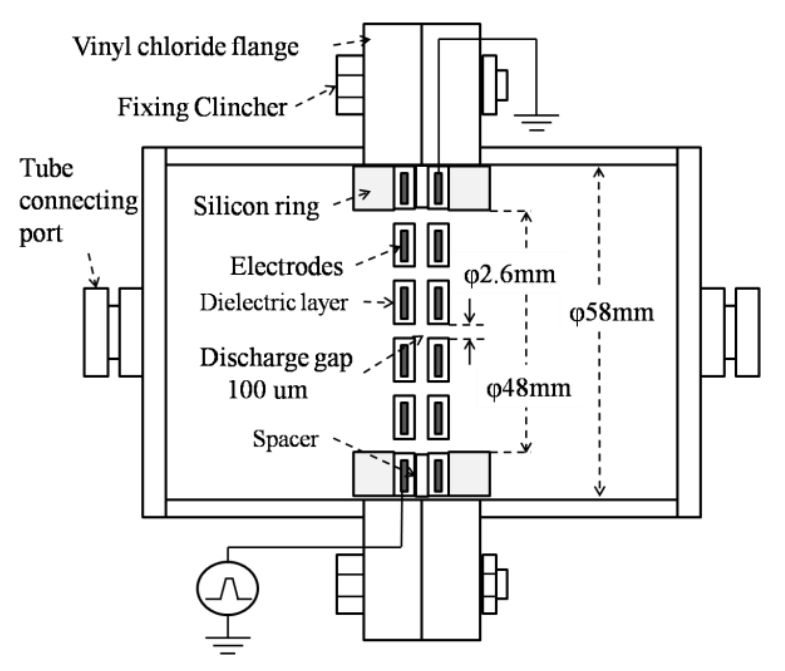


The microplasma reactor is shown in Figure 1. A laboratory-made Marx Generator with MOSFET switches and a pulse power supply which consisted in a function generator (Tektronix, AFG3021B) and a high voltage amplifier (Trek, MODEL 5/80) were used as power supplies to energize the electrodes. The Marx Generator generates negative pulses up to $-1.6 \mathrm{kV}$, rise time $100 \mathrm{~ns}$ and pulse width $1.5 \mu$ s. It has two stages, as shown in Figure 2. The capacitors are linked in parallel connection when the MOSFET switches are opened. When voltage is applied the capacitors are charged at a value $\mathrm{V}$ and by turning on the MOSFET switches, the capacitors will discharge in a series connection multiplying the output voltage by the number of capacitors, in this case $2 \mathrm{~V}$ [10].

Figure 2. Marx generator circuit.

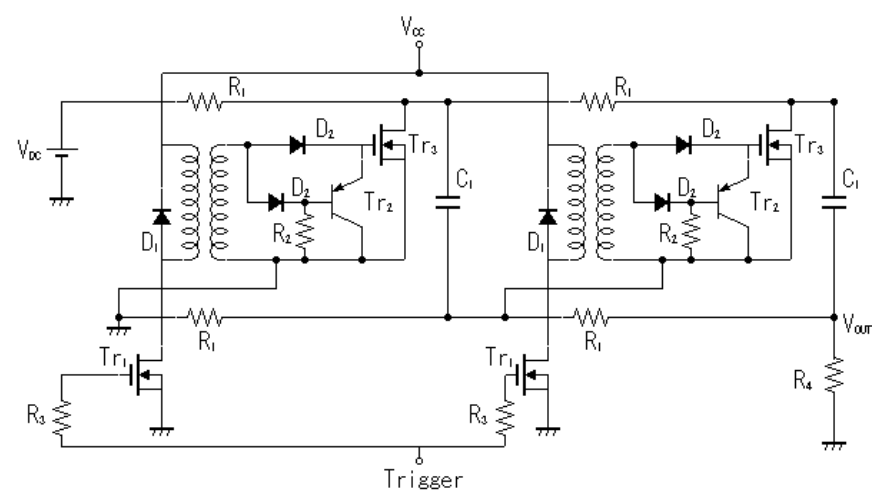

The DC power supply which charges the capacitors has the maximum output of $0.8 \mathrm{kV}$, thus the Marx generator circuit can generate negative pulses up to $-1.6 \mathrm{kV}$. An image of the Marx Generator circuit is shown in Figure 3. The circuit board has a relatively small size with dimensions of $160 \mathrm{~mm} \times 240 \mathrm{~mm}$.

Figure 3. Image of the Marx Generator circuit.

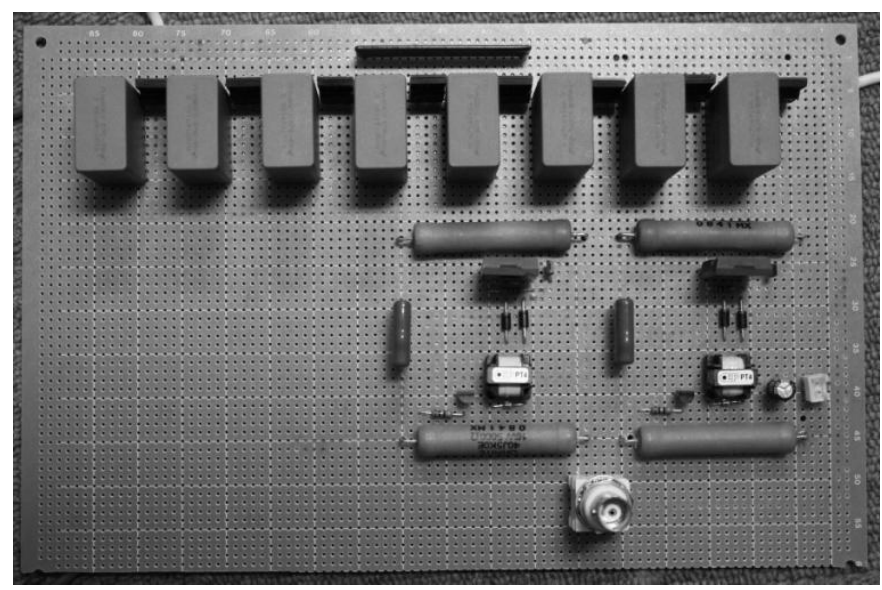

Figure 4 shows an experimental setup for the one pass treatment method. A gas cylinder of HCHO (HCHO gas concentration: $19.6 \mathrm{ppm}$ ) and air was used to obtain a concentration of $0.7 \mathrm{ppm} \mathrm{HCHO}$ in air. Gas flow rate and gas humidity in the microplasma reactor were set at $5 \mathrm{~L} / \mathrm{min}$ and $0 \%$, respectively. The gas is flown through electrodes, thus $\mathrm{HCHO}$ could be decomposed due to the action of various radicals and active species $\left(\mathrm{N}^{*}, \mathrm{~N}_{2}{ }^{*}, \mathrm{O}^{*}, \mathrm{OH}^{*}\right.$, etc. $)$, the intense electric field and ultraviolet light [10]. Before and after treatment the air was analyzed by an ozone monitor (Seki Electronics, 
SOZ-3300) for ozone quantity measurement, a NOx analyzer (Shimadzu, NOA 7000) for NOx quantity measurement, and an high performance liquid chromatography (HPLC, Agilent, 1100 series). For measuring the HCHO concentration by HPLC a dinitrophenylhydrazine (DNPH) cartridge was used to evaluate the processing ability of $\mathrm{HCHO}$ by the microplasma. The discharge power of an HV amplifier and a Marx Generator was set to $0.3 \mathrm{~W}$ to energize the microplasma electrodes. Frequency of both power supplies was set at $1.0 \mathrm{kHz}$. A fragrance analyzer (Shimadzu, FF-2A) with 10 semiconductor sensors was used for the aroma sensory assessment.

Figure 4. An experimental setup for one pass treatment.

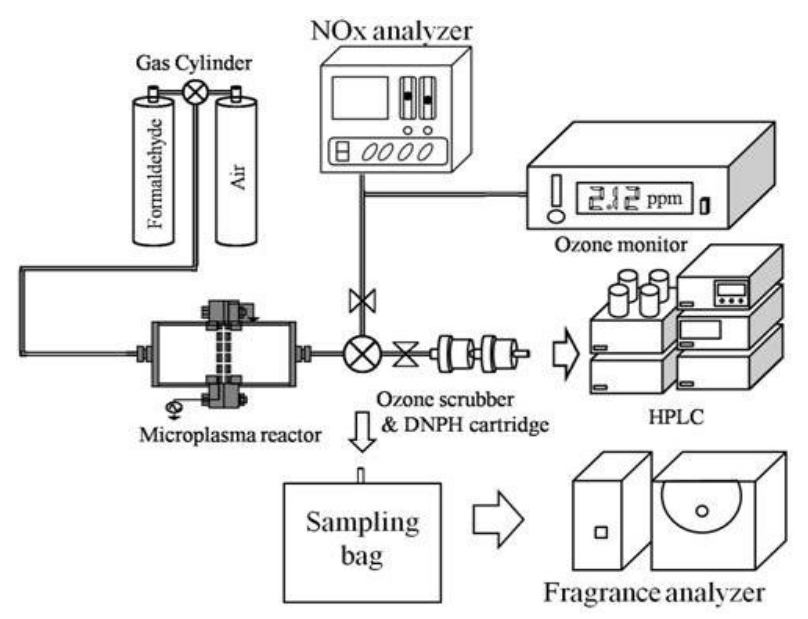

\section{Results and Discussion}

The waveforms of the discharge voltage and corresponding discharge current from the HV amplifier are shown in Figure 5. Spike currents occurred due to the microdischarges, convoluted on the current waveform, and were observed in addition to the capacitive current at steepest slopes of the waveform. Typical pulse width was about $12 \mu$ s and rising time was about $5 \mu \mathrm{s}$.

Figure 5. Discharge voltage and corresponding discharge current by a high voltage amplifier.

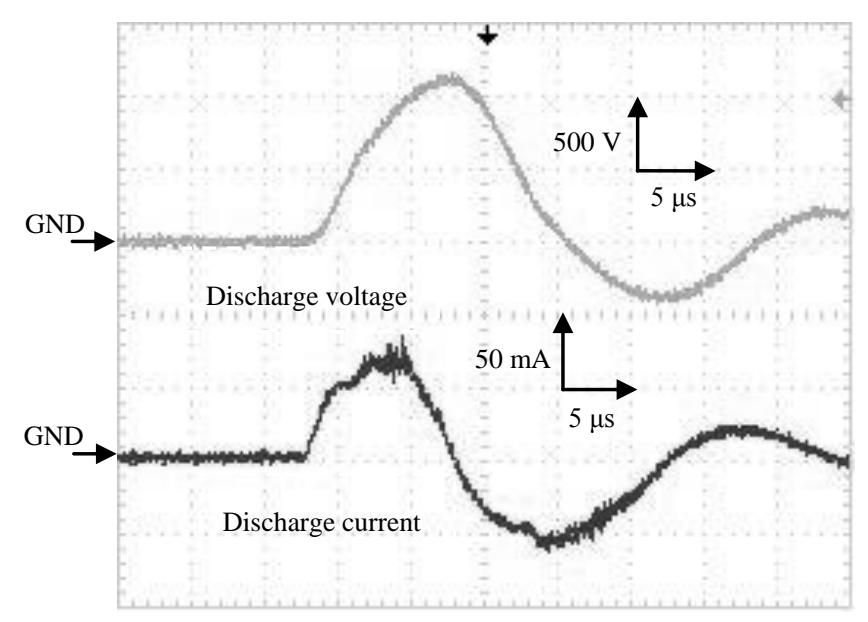

The waveforms of discharge voltage and corresponding discharge current from the Marx Generator are shown in Figure 6. Rise time of the discharge voltage from Marx Generator was 100 ns, and fall time was $4 \mu \mathrm{s}$. A sharp discharge current was observed. 
Figure 6. Discharge voltage and corresponding discharge current by a Marx Generator.

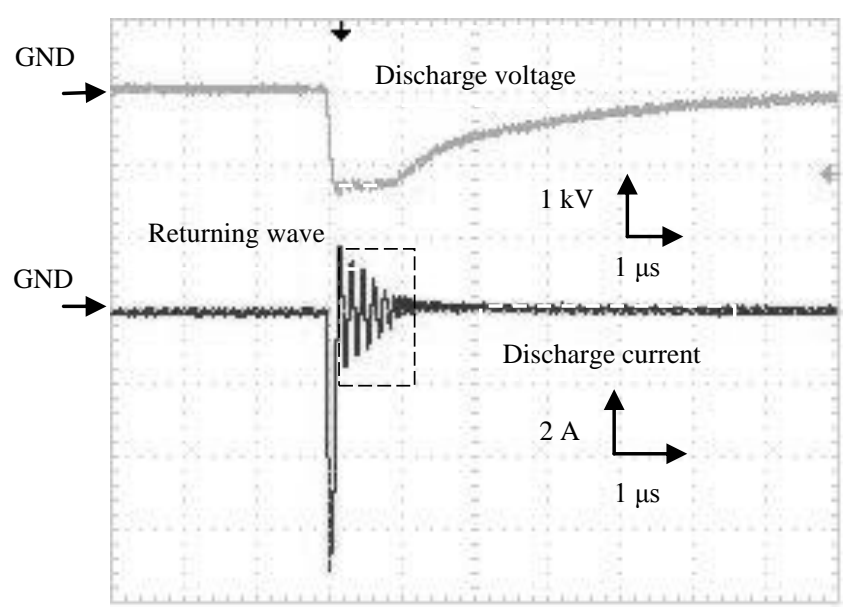

The characteristics of discharge power versus discharge voltage for both the HV amplifier and Marx Generator are shown in Figure 7. Discharge power was estimated by integrating the waveform of voltage and current product in time using an oscilloscope and dividing it by time in order to obtain the power for one cycle. The current amplitude varied with the discharge voltage and had higher peak values for the Marx Generator, as shown in Figures 5 and 6.

Discharge power of the Marx Generator at $1.0 \mathrm{kV}$ was lower than that at $0.9 \mathrm{kV}$. This could be explained by the decrease of transient form of the discharge current when the microplasma discharge started to occur at $1 \mathrm{kV}$. As the discharge voltage increases, the discharge power increases. Discharge power of the $\mathrm{HV}$ amplifier was $0.312 \mathrm{~W}$ at $1.2 \mathrm{kV}$ for one cycle, and discharge power of the Marx Generator was $0.331 \mathrm{~W}$ at $1.3 \mathrm{kV}$.

Figure 7. Characteristic discharge power of both power supplies.

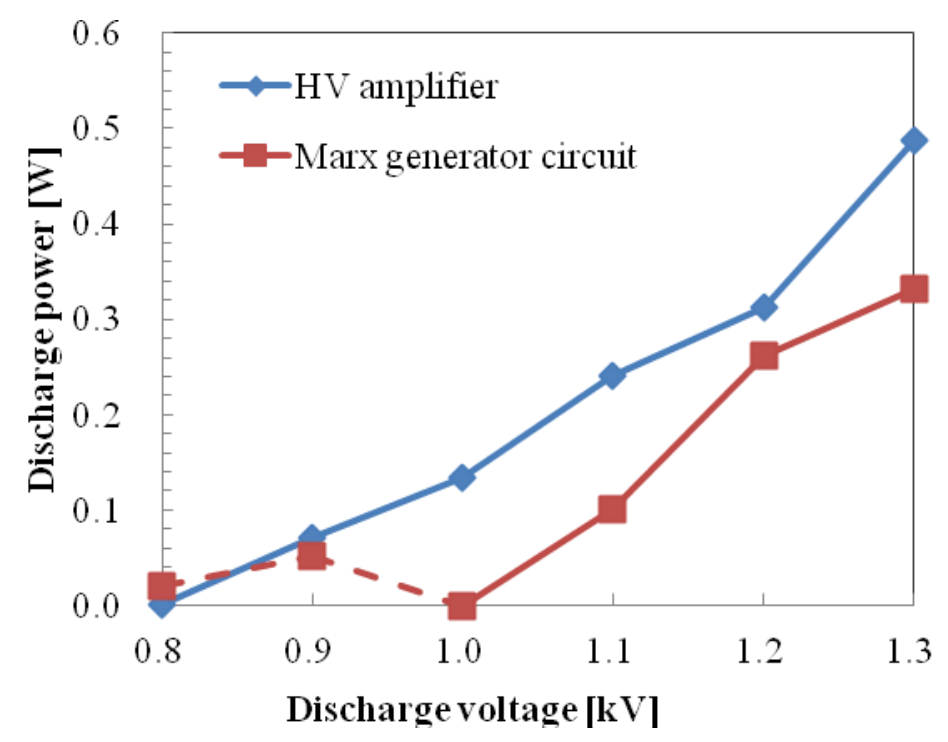

As previously reported in [11], the emission spectrum from the microplasma discharge in $\mathrm{N}_{2}$ with water vapors when a high voltage amplifier was used to energize the electrodes, showed $\mathrm{N}_{2}$ Second Positive System ( $\mathrm{N}_{2}$ SPS) peaks at 315.9, 337.1, 357.7, 367.2, 371.1, 375.5, 380.5, $394.3 \mathrm{~nm}$ that were observed due to electron collision [12-14], and $\mathrm{OH}$ peaks at $306.4 \mathrm{~nm}, 307.8 \mathrm{~nm}$ and $308.9 \mathrm{~nm}[15,16]$. 
Production of $\mathrm{OH}$ and $\mathrm{H}$ radicals was due to the electron impact dissociation of $\mathrm{H}_{2} \mathrm{O}$ vapors [6,17]:

$$
\mathrm{e}+\mathrm{H}_{2} \mathrm{O} \rightarrow \mathrm{e}+\mathrm{H}+\mathrm{OH}
$$

Excited state $\mathrm{O}\left({ }^{1} \mathrm{D}\right)$ could dissociate $\mathrm{H}_{2} \mathrm{O}$ to generate $\mathrm{OH}$ :

$$
\mathrm{O}\left({ }^{1} \mathrm{D}\right)+\mathrm{H}_{2} \mathrm{O} \rightarrow 2 \mathrm{OH} \mathrm{k}=2.2 \times 10^{-10}
$$

and also excited $\mathrm{N}_{2}$ :

$$
\mathrm{N}_{2} *+\mathrm{H}_{2} \mathrm{O} \rightarrow \mathrm{OH}+\mathrm{H}+\mathrm{N}_{2} \mathrm{k}=4.2 \times 10^{-11}
$$

When air is used as carrier gas with water droplets, active species and ozone are generated by the microplasma:

$$
\begin{gathered}
\mathrm{e}+\mathrm{O}_{2} \rightarrow \mathrm{e}+\mathrm{O}\left({ }^{3} \mathrm{P}\right)+\mathrm{O}\left({ }^{3} \mathrm{P},{ }^{1} \mathrm{D}\right) \\
\mathrm{N}_{2}\left(\mathrm{~A}^{3} \Sigma_{\mathrm{u}}{ }^{+}\right)+\mathrm{O}_{2} \rightarrow \mathrm{N}_{2}+\mathrm{O}_{2} \mathrm{k}=2.5 \times 10^{-12} \times(\mathrm{T} / 300)^{0.55} \\
\mathrm{~N}_{2}\left(\mathrm{~A}^{3} \Sigma_{\mathrm{u}}^{+}\right)+\mathrm{O}_{2} \rightarrow \mathrm{N}_{2}+\mathrm{O}+\mathrm{O} \\
\mathrm{N}_{2}\left(\mathrm{~B}^{3} \Pi_{\mathrm{g}}\right)+\mathrm{O}_{2} \rightarrow \mathrm{N}_{2}+\mathrm{O}+\mathrm{O} \mathrm{k}=3.0 \times 10^{-10} \\
\mathrm{~N}_{2}\left(\mathrm{a}^{\cdot} \Sigma_{\mathrm{u}}{ }^{-}\right)+\mathrm{O}_{2} \rightarrow \mathrm{N}_{2}+\mathrm{O}+\mathrm{O} \mathrm{k}=2.8 \times 10^{-11} \\
\mathrm{O}\left({ }^{3} \mathrm{P}\right)+\mathrm{O}_{2}+\mathrm{M} \rightarrow \mathrm{O}_{3}+\mathrm{M}
\end{gathered}
$$

The previously mentioned active species and radicals contribute to the process of decomposition of HCHO through the following reactions:

$$
\begin{aligned}
& \mathrm{HCHO}+\mathrm{O} \rightarrow \mathrm{HCO}+\mathrm{OH} \mathrm{k}=2.99 \times 10^{-11} \exp (-1543 / \mathrm{T}) \\
& \mathrm{HCHO}+\mathrm{OH} \rightarrow \mathrm{HCO}+\mathrm{H}_{2} \mathrm{O} \mathrm{k}=1.6 \times 10^{-11} \exp (-110 / \mathrm{T}) \\
& \mathrm{HCHO}+\mathrm{OH} \rightarrow \mathrm{H}+\mathrm{HCOOH} \mathrm{k}=2 \times 10^{-13} \\
& \mathrm{HCHO}+\mathrm{H} \rightarrow \mathrm{HCO}+\mathrm{H}_{2} \mathrm{k}=3.64 \times 10^{-16} \mathrm{~T}^{1.77} \exp (-1510 / \mathrm{T}) \\
& \mathrm{HCOOH}+\mathrm{OH} \rightarrow \mathrm{H}_{2} \mathrm{O}+\mathrm{CO}_{2}+\mathrm{H} \mathrm{k}=4.80 \times 10^{-13} \\
& \mathrm{HCO}+\mathrm{M} \rightarrow \mathrm{H}+\mathrm{CO}+\mathrm{M} \mathrm{k}=8.50 \times 10^{-3} \mathrm{~T}^{-2.14} \exp (-10278 / \mathrm{T}) \\
& \mathrm{HCO}+\mathrm{H}_{2} \rightarrow \mathrm{HCHO}+\mathrm{H} \mathrm{k}=3 \times 10^{-18} \mathrm{~T}^{2.0} \exp (-8972 / \mathrm{T}) \\
& \mathrm{HCO}+\mathrm{O}_{2} \rightarrow \mathrm{HO}_{2}+\mathrm{CO} \mathrm{k}=8.50 \times 10^{-11} \exp (-850 / \mathrm{T}) \\
& \mathrm{HCO}+\mathrm{H} \rightarrow \mathrm{H}_{2}+\mathrm{CO} \mathrm{k}=2 \times 10^{-10} \\
& \mathrm{HCO}+\mathrm{O} \rightarrow \mathrm{CO}_{2}+\mathrm{Hk}=5 \times 10^{-11} \\
& \mathrm{HCO}+\mathrm{O} \rightarrow \mathrm{CO}+\mathrm{OH} \mathrm{k}=5 \times 10^{-11} \\
& \mathrm{HCO}+\mathrm{OH} \rightarrow \mathrm{H}_{2} \mathrm{O}+\mathrm{CO} \mathrm{k}=5 \times 10^{-11} \\
& \mathrm{HCO}+\mathrm{HO}_{2} \rightarrow \mathrm{OH}+\mathrm{H}+\mathrm{CO}_{2} \mathrm{k}=5 \times 10^{-11} \\
& \mathrm{HCO}+\mathrm{H}_{2} \mathrm{O}_{2} \rightarrow \mathrm{CH}_{2} \mathrm{O}+\mathrm{HO}_{2} \mathrm{k}=1.70 \times 10^{-13} \exp (-3486 / \mathrm{T}) \\
& \mathrm{HCO}+\mathrm{H}_{2} \mathrm{O} \rightarrow \mathrm{CH}_{2} \mathrm{O}+\mathrm{OH} \mathrm{k}=3.90 \times 10^{-16} \mathrm{~T}^{1.35} \exp (-13146 / \mathrm{T})
\end{aligned}
$$




$$
\begin{gathered}
\mathrm{HCO}+\mathrm{HCO} \rightarrow \mathrm{CH}_{2} \mathrm{O}+\mathrm{CO} k=3 \times 10^{-11} \\
\mathrm{HCO}+\mathrm{O}_{3} \rightarrow \mathrm{H}+\mathrm{O}_{2}+\mathrm{CO}_{2}
\end{gathered}
$$

The process of HCHO decomposition was reported by Storch and Kushner and they stated that the destruction of $\mathrm{HCHO}$ results predominantly from chemical attack by $\mathrm{OH}$ and $\mathrm{O}$ radicals via $\mathrm{HCO}$. We reported in [11] that $\mathrm{O}$ radicals and $\mathrm{OH}$ radicals are the main species which are contributing to formaldehyde removal according to reactions (10) and (11). In both cases HCO results, which furthermore reacts with $\mathrm{HCO}$ (reaction 25) to give formaldehyde and $\mathrm{CO}$ or reacts with $\mathrm{O}_{2}$ (reaction 17) to obtain $\mathrm{HO}_{2}$ and $\mathrm{CO} . \mathrm{HO}_{2}$ is decomposed according to reactions (27) and (28):

$$
\begin{gathered}
\mathrm{HO}_{2}+\mathrm{O} \rightarrow \mathrm{OH}+\mathrm{O}_{2} \mathrm{k}=4.52 \times 10^{-11} \\
\mathrm{HO}_{2}+\mathrm{OH} \rightarrow \mathrm{H}_{2} \mathrm{O}+\mathrm{O}_{2} \mathrm{k}=8.00 \times 10^{-11}
\end{gathered}
$$

The removal ratio of $\mathrm{HCHO}$ in one pass using a microplasma reactor powered by the HV amplifier by varying the discharge power up to $0.3 \mathrm{~W}$ is shown in Figure 8 . The removal ratio was considered as (Removed Concentration $\times 100$ )/Initial Concentration. Initial HCHO concentration of the sample gas was set at $0.707 \mathrm{ppm}$ by diluting $\mathrm{HCHO}$ (initial HCHO concentration: $19.6 \mathrm{ppm}$ ) by adding pure air from a gas cylinder. The removal ratio of $\mathrm{HCHO}$ at $0.07 \mathrm{~W}$ was $35.4 \%$. At this discharge power the generated ozone concentration was quite low (below $0.2 \mathrm{ppm}$ ). As the value of discharge power increases the $\mathrm{HCHO}$ removal ratio and generated ozone concentration also increase. The HCHO removal ratio reached $95.8 \%$ at the discharge power of $0.24 \mathrm{~W}$ and $3.46 \mathrm{ppm}$ of ozone was generated at this discharge power. The removal ratio of $\mathrm{HCHO}$ was saturated at around $97 \%$ when the discharge power was increased above $0.3 \mathrm{~W}$. The generated ozone concentration increased with the increase of discharge power. Thus the maximum value of ozone concentration was $8.22 \mathrm{ppm}$ at $0.312 \mathrm{~W}$.

Figure 8. $\mathrm{HCHO}$ and $\mathrm{O}_{3}$ concentration in one pass treatment by $\mathrm{HV}$ amplifier.

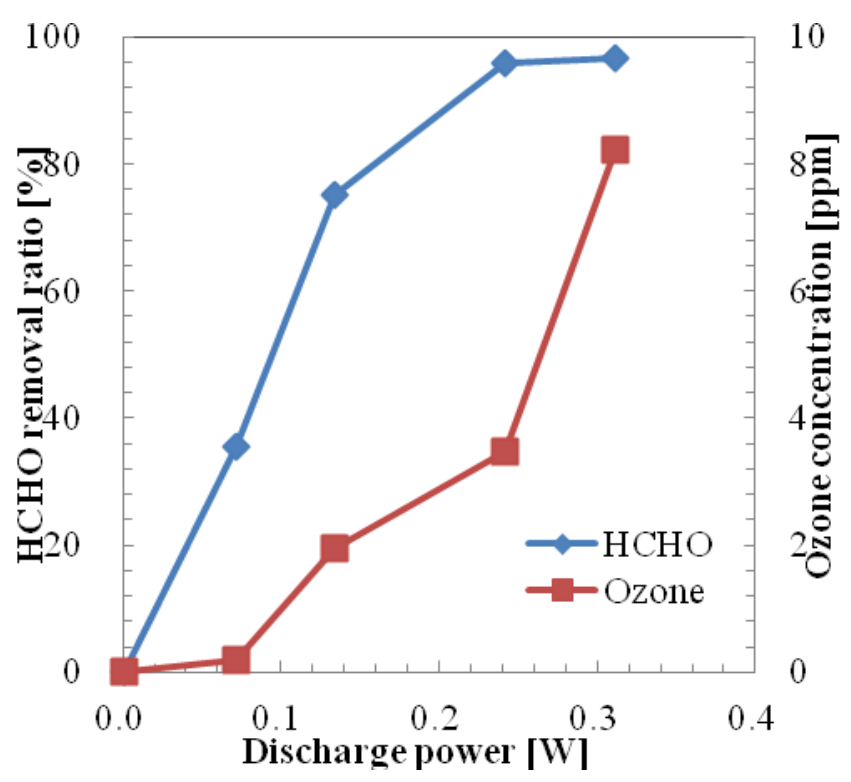


Ozone is known to be toxic to the human body at concentrations above $100 \mathrm{ppb}$. Thus the optimal value for the discharge voltage, in the HCHO removal process when a HV amplifier was used, could be considered $0.9 \mathrm{kV}$ (discharge power: $0.07 \mathrm{~W}$ ) due to the relatively high removal ratio of $\mathrm{HCHO}$ and low generated ozone concentration.

The removal ratio of $\mathrm{HCHO}$ in one pass using a microplasma reactor powered by the Marx Generator is shown in Figure 9. Initial concentration of $\mathrm{HCHO}$ was set at $0.762 \mathrm{ppm}$. Removal ratio of $\mathrm{HCHO}$ was $30.7 \%$ at the discharge power of $0.102 \mathrm{~W}$. At this discharge power, a low ozone concentration $(0.16 \mathrm{ppm})$ was generated. The HCHO removal ratio reached $96.2 \%$ when the discharge power was increased to $0.331 \mathrm{~W}$. The maximum generated ozone concentration of $3.81 \mathrm{ppm}$ could be considered low, compared with the case when an HV amplifier was used.

Figure 9. $\mathrm{HCHO}$ and $\mathrm{O}_{3}$ concentration in one pass treatment by Marx Generator.

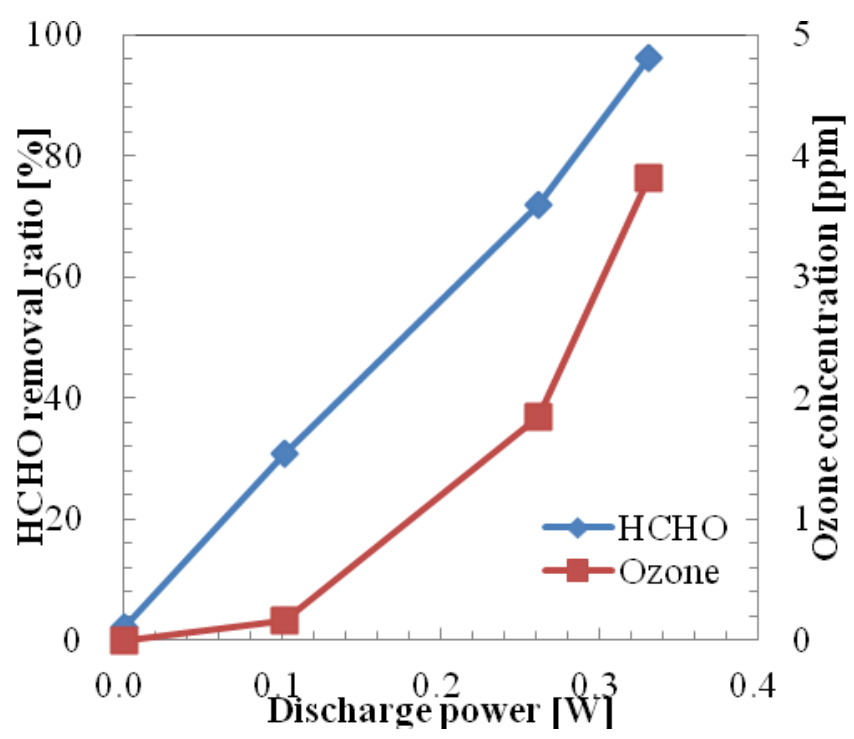

As previously mentioned, in the one pass $\mathrm{HCHO}$ treatment process by microplasma the sample gas was obtained by mixing $\mathrm{HCHO}$ from a gas cylinder with air from another gas cylinder. Thus the humidity of the mixed gas was $0 \%$. In the case of no humidity in air, the $\mathrm{OH}$ radical was not generated by the reactions (1-3). The reactions of the HCHO removal process are considered to be (10-26). NOx generation characteristics by both power supplies are shown in Figure 10.

NOx was generated according to the following chemical reactions (29-34):

$$
\begin{gathered}
\mathrm{N}_{2}+\mathrm{e} \rightarrow \mathrm{N}\left({ }^{4} \mathrm{~S}\right)+\mathrm{N}\left({ }^{4} \mathrm{~S},{ }^{2} \mathrm{D}\right)+\mathrm{e} \\
\mathrm{N}_{2}+\mathrm{e} \rightarrow \mathrm{N}_{2}\left(\mathrm{~A}^{3} \Sigma_{\mathrm{u}}^{+}\right)+\mathrm{e} \\
\mathrm{N}_{2}\left(\mathrm{~A}^{3} \Sigma_{\mathrm{u}}^{+}\right)+\mathrm{O} \rightarrow \mathrm{NO}+\mathrm{N}^{*}\left({ }^{2} \mathrm{D}\right) \\
\mathrm{N}\left({ }^{2} \mathrm{D}\right)+\mathrm{O}_{2} \rightarrow \mathrm{NO}+\mathrm{O} \\
\mathrm{O}_{3}+\mathrm{NO} \rightarrow \mathrm{NO}_{2}+\mathrm{O}_{2} \\
\mathrm{NO}+\mathrm{OH} \rightarrow \mathrm{NO}+\mathrm{H}
\end{gathered}
$$

NOx started to be generated above $0.1 \mathrm{~W}$ when a $\mathrm{HV}$ amplifier was used. After increasing the discharge power more than $0.1 \mathrm{~W}$, NOx concentration increased to $0.3 \mathrm{ppm}$ at $0.312 \mathrm{~W}$. 
Figure 10. NOx generation by both power supplies.

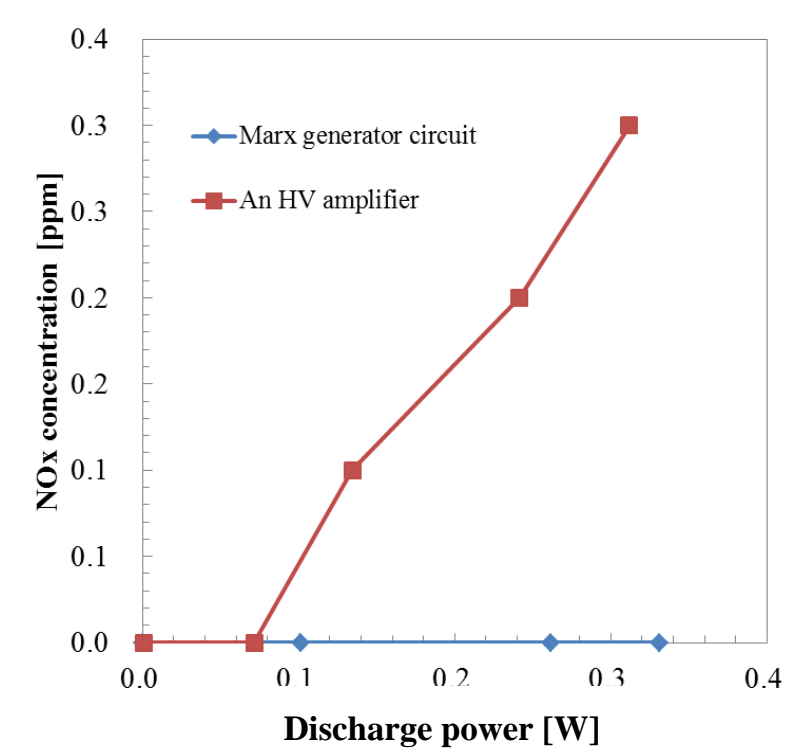

In the case when a Marx Generator circuit was used to generate the microplasma, no NOx generation was measured, even at $0.331 \mathrm{~W}$. The discharge current of a Marx Generator circuit had short duration and generation of $\mathrm{O}_{3}$ was about $1 / 3$ at same discharge voltage by an $\mathrm{HV}$ amplifier. According to Rousseau et al. $\mathrm{NO}$ and $\mathrm{NO}_{2}$ generation depends "only on the duty cycle ratio" [23]. The Duty Cycle Ratio (DCR) is defined as the ratio of the pulse duration to the pulse period. The DCRs for the Marx Generator and HV amplifier were $0.15 \%$ and $1.2 \%$, respectively, considering the pulse width of the Marx generator and HV amplifier of $1.5 \mu \mathrm{s}$ and $12 \mu \mathrm{s}$, respectively, at $1 \mathrm{kHz}$. The electron density is not constant during discharge but during the pulse on period the highest electron density corresponds to the peak of the discharge current. The DCR for the Marx Generator could be considered smaller than $0.15 \%$ due to the fact that the width of the discharge current is smaller than the width of the discharge voltage. We previously reported for the microplasma discharge in a $\mathrm{N}_{2} / \mathrm{Ar}$ mixture an electron density of ne $=1.6 \times 10^{12} \mathrm{~cm}^{-3}$ calculated for the peak intensity of the discharge current [24]. Electron density was estimated also by Shao et al. [25] for a DBD discharge in air for a $2 \mathrm{~mm}$ discharge gap at $4.1 \times 10^{11} \mathrm{~cm}^{-3}$. For an atmospheric pressure microwave-induced plasma in Ar the electron density reached ne $=3 \times 10^{14} \mathrm{~cm}^{-3}$ [26]. This could contribute to the low NOx concentration. Considering that NOx are well known for their toxicity, in a further implementation of microplasma as a technology for cleaning the room air, the Marx Generator could be considered as the solution for the power supply.

The results of smell analysis are shown in Figures 11 and 12. Ozone was collected from the sample gas by passing through an ozone scrubber (GL Science 5010-23510). The smell similarities of sample gas against various standard gases are shown as a cobweb chart in Figure 11. The highest smell similarity of sample gas before microplasma treatment was measured for the aldehyde series, next was the hydrogen sulfide series and ester series. Smell similarity of the sample gas to the aldehyde series, hydrogen sulfide and ester series was reduced after microplasma treatment. Other smell component similarity of the sample gas after microplasma treatment were also reduced or maintained at same level compared with control sample gas consisting in pure air flowed into the one pass chamber. 
Figure 11. The smell similarity of before and after microplasma treatment.

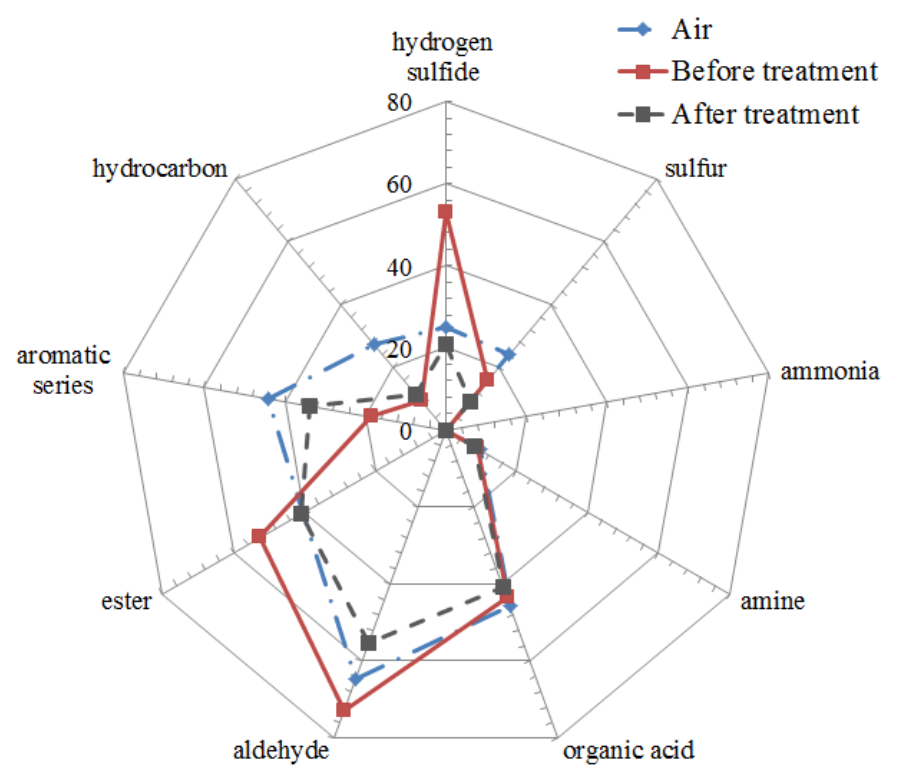

Figure 12. The odor index of before, after HCHO treatment and room air.

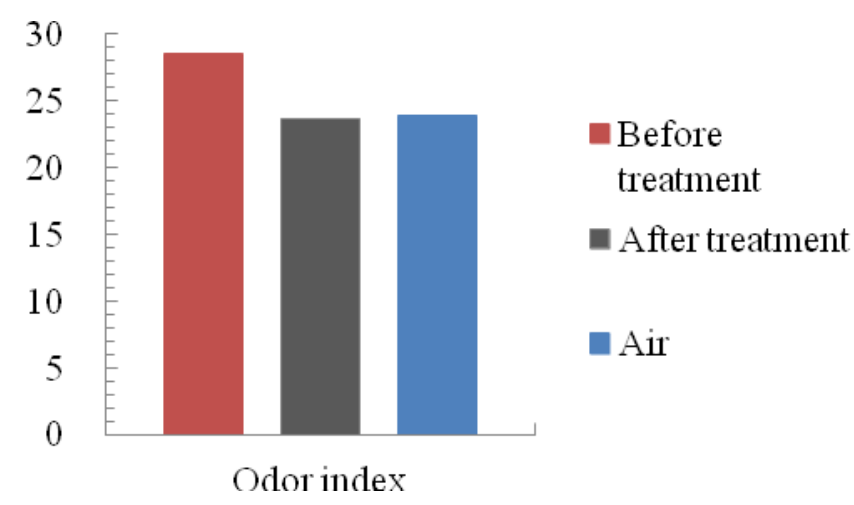

The value of the odor index of the control sample gas, before and after microplasma treatment gases is shown in Figure 12. Sample gas showed the highest value before treatment by microplasma. The control sample gas showed the middle value and the lowest value of odor index for the treated gas. These results show that the microplasma could also treat residual smells in the one pass chamber.

\section{Conclusions}

A high voltage amplifier and a Marx Generator were used for the removal of indoor air contaminants by microplasma. The following conclusions were obtained:

1. Removal ratio of formaldehyde using one pass microplasma reactor and a high voltage amplifier was $96.6 \%$ at the discharge power of $0.312 \mathrm{~W}$ with $8.22 \mathrm{ppm}$ of ozone generation. The HCHO removal ratio reached $96.2 \%$ with $3.81 \mathrm{ppm}$ of ozone generation at the discharge power of 0.331 $\mathrm{W}$ when a Marx Generator powered the one pass microplasma reactor. 
2. $0.3 \mathrm{ppm}$ of NOx was generated using a one pass microplasma reactor powered by an $\mathrm{HV}$ amplifier at a discharge power of $0.312 \mathrm{kV}$. In contrast, NOx was not observed when a Marx Generator powered the one pass microplasma reactor at any power range up to $0.331 \mathrm{~W}$.

3. The similarity of bad smell components of sample gas was reduced, especially for the aldehyde series, hydrogen sulfide series and ester series after microplasma treatment. Additionally, the value of odor index was also reduced by the odor eliminating effect of the microplasma.

\section{References}

1. Wolkoff, P.; Nielsen, G.D. Organic compounds in indoor air-their relevance for perceived indoor air quality? Atmos. Environ. 2001, 35, 4407-4417.

2. Seki, A.; Takigawa, T.; Kishi, R.; Sakabe, K.; Torii, S.; Tanaka, M.; Yoshimura, T.; Morimoto, K.; Katoh, T.; Kira, S.; Aizawa, Y. Review of 'Sick House Syndrome. Jpn. J. Hyg. 2007, 62, 939-948.

3. Chiper, A.S.; Simiand, N.B.; Jorand, F.; Pasquiers, S.; Popa, G.; Positel, C. Influence of water vapour on acetaldehyde removal efficiency by DBD. J. Otpoelectron. Advan. Mater. 2006, 8, 208-211.

4. Faungnawakij, K.; Sano, N.; Yamamoto, D.; Kanki, T.; Charinpanitkul, T.; Tanthapanichakoon, W. Removal of acetaldehyde in air using a wetted-Wall corona discharge reactor. Chem. Eng. J. 2004, 103, 115-122.

5. Iza, F.; Kim, G.J.; Lee, S.M.; Lee, J.K.; Walsh, J.L.; Zhang, Y.T.; Kong, M.G. Microplasmas: Sources, particle kinetics, and biomedical applications. Plasma Process. Polym. 2008, 5, $322-344$.

6. Liang, W.; Li, J.; Li, J.X.; Zhu, T.; Jin, Y.Q. Formaldehyde removal from gas streams by means of $\mathrm{NaNO}_{2}$ dielectric barrier discharge plasma. J. Hazard. Mater. 2010, 175, 1090-1095.

7. Foest, R.; Schmidt, M.; Becker, K. Microplasmas: An emerging field of low-temperature plasma science and technology. Int. J. Mass. Spectrom. 2006, 248, 87-102.

8. Carey, W.J.; Mayes, J.R. Marx Generator Design and Performance. In Proceedings of Conference Record of the International Power Modulator Symposium, Hollywood, CA, USA, 30 June-3 July 2002; pp. 625-628,

9. Storch, D.G.; Kushner, M.J. Destruction mechanisms for formaldehyde in atmospheric temperature plasmas. J. Appl. Phys. 1993, 73, 51-55.

10. Blajan, M.; Muramatsu, S.; Ishii, T.; Mimura, H.; Shimizu, K. Emission Spectroscopy of Microplasma Using a Pulsed Power Supply. In Proceedings of 2009 Annual Meeting, IESJ, Tokyo, Japan, 10-11 September 2009; pp. 11-16.

11. Shimizu, K.; Blajan, M.; Kuwabara, T. Removal of indoor air contaminant by atmospheric microplasma. IEEE Trans. Ind. Appl. 2011, 47, 2351-2358.

12. Lofthus, A.; Krupenie, P.H. The spectrum of molecular nitrogen. J. Phys. Chem. Ref. Data 1977, 6, 113-307.

13. Shimizu, K.; Ishii, T.; Blajan, M. Emission spectroscopy of pulsed power microplasma for atmospheric pollution control. IEEE Trans. Ind. Appl. 2010, 46, 1125-1131. 
14. Kozlov, K.V.; Wagner, H.-E. Progress in spectroscopic diagnostics of barrier discharges. Contrib. Plasma Phys. 2007, 47, 26-33.

15. Liu, F.; Wang, W.; Wang, S.; Zheng, W.; Wang, Y. Diagnosis of OH radical by optical emission spectroscopy in a wire-plate bi-directional pulsed corona discharge. J. Electrostatics 2007, 65, 445-451.

16. Shimizu, K.; Yamada, M.; Kanamori, M.; Blajan, M. Basic study of bacteria inactivation at low discharge voltage by using microplasmas. IEEE Trans. Ind. Appl. 2010, 46, 641-649.

17. Atkinson, R.; Baulch, D.L.; Cox, R.A.; Crowley, J.N.; Hampson, R.F.; Hynes, R.G.; Jenkin, M.E.; Rossi, M.J.; Troe, J. Evaluated kinetic and photochemical data for atmospheric chemistry: Volume 1-Gas phase reactions of OX, HOX, NOX and SOX species. Atomos. Chem. Phys. 2004, 4, 1461-1738.

18. Atkinson, R.; Baulch, D.L.; Cox, R.A.; Crowley, J.N.; Hampson, R.F.; Hynes, R.G.; Jenkin, M.E.; Rossi, M.J.; Troe, J. Evaluated kinetic and photochemical data for atmospheric chemistry: Volume 2-Gas phase reactions of organic species. Atmos. Chem. Phys. 2006, 6, 3625-4055.

19. NIST Chemical Kinetics Database. Available online: http://kinetics.nist.gov/kinetics/index.jsp (accessed on 22 October 2012).

20. Park, S.Y.; Deshwal, B.R.; Moon, S.H. NOx removal from the flue gas of oil-fired boiler using a multistage plasma-catalyst hybrid system. Fuel Process. Technol. 2008, 89, 540-548.

21. Santillan, M.; Vincent, A.; Santirso, E.; Amouroux, J. Design of a DBD wire-cylinder reactor for NOx emission control: experimental and modeling approach. J. Clean. Prod. 2008, 16, 198-207.

22. Orszagh, J.; Skalny, J.D.; Mason, N.J. Ozone formation in a coaxial DC Corona discharge under carbon dioxide gas flow. Plasma Processes Polym. 2007, 4, 694-700.

23. Rousseau, A.; Gatilova, L.V.; Röpcke, J.; Meshchanov, A.V.; Ionikh, Y.Z. NO and $\mathrm{NO}_{2}$ production in pulsed low pressure de discharge. Appl. Phys. Lett. 2005, 86, 211-501.

24. Blajan, M.; Shimizu, K. Temporal evolution of dielectric barrier discharge microplasma. Appl. Phys. Lett. 2012, 101, 104101.

25. Jovicevic, S.; Ivkovic, M.; Pavlovic, Z.; Konjevic, N. Parametric study of an atmospheric pressure microwave-induced plasma of the mini MIP torch-I. Two-dimensional spatially resolved electron-number density measurements. Spectrochim. Acta B: Atom Spectros. 2000, 55, 1879-1893.

26. Shao, T.; Zhang, C.; Yu, Y.; Niu, Z.; Jiang, H.; Xu, J.; Li, W.; Yan, P.; Zhou, Y. Discharge characteristic of nanosecond-pulse DBD in atmospheric air using magnetic compression pulsed power generator. Vacuum 2012, 86, 876-880.

(C) 2012 by the authors; licensee MDPI, Basel, Switzerland. This article is an open access article distributed under the terms and conditions of the Creative Commons Attribution license (http://creativecommons.org/licenses/by/3.0/). 